\title{
The role of enriched foods in infant and child nutrition
}

\author{
Teresa Shamah* and Salvador Villalpando \\ Centro de Investigación en Nutrición y Salud, Instituto Nacional de Salud Pública, Av. Universidad 655, Col. Sta. María \\ Ahuacatitlán, CP 62508 Cuernavaca, Morelos, México
}

\begin{abstract}
Since the last century, fortified and enriched foods are products whose original composition has been modified-through addition of essential nutrients - to satisfy specific population needs. For the fortification of foods to have a positive impact on nutritional status, the micronutrients added must be well absorbed and utilized by the organism (bioavailability). Diverse factors affect bioavailability, such as the nutritional status of individuals, the presence in the diet of substances which facilitate or inhibit its absorption, interactions among micronutrients, illnesses, and chemical characteristics of the compound used for fortification. In countries such as Chile, Venezuela and Mexico, important effects have been demonstrated in reducing iron deficiency anaemia in children under 5 years of age. In less than a decade, the salt iodization programme has also proven its effectiveness. Other programmes have fortified foods with $\mathrm{Zn}$, vitamin A and folic acid, which are deficient in infants and children of many populations. In summary, food fortification is a low-cost, relatively simple strategy that may reach a wide range of people, and contribute to reducing the high prevalence of micronutrient deficiencies affecting children, especially in poor countries. The costs due to losses of human capital and their repercussions on health and future development are very high. Building links among academic researchers, politicians, food manufacturers and consumers is essential in order for food fortification to be efficacious and effective, and therefore should be considered as part of an integral strategy to combat micronutrient deficiencies.
\end{abstract}

Fortified and enriched foods: Micronutrient deficiencies

Chronic malnutrition is responsible for millions of childhood deaths globally. Those who survive from chronic malnutrition are less likely to achieve a secure and productive life due to the greater morbidity and associated biological fragility (Svedberg, 2000).

Micronutrient deficiencies, i.e. vitamin and mineral deficiencies, is the most generalized form of malnutrition in the world, especially affecting women and children. It is estimated that between 4 and 5 billion people live with $\mathrm{Fe}$ deficiency, and an estimated 2 billion are calculated to have anaemia (UNICEF, 1998; World Health Organization/ UNICEF/United Nations University, 2001).

\section{A global vision of chronic malnutrition and micronutrient deficiency anaemia, iron and zinc deficiencies}

The prevalence of iron deficiency anaemia (IDA) among preschool children in 1985 ranged between 25 and $50 \%$ in developing countries and between 2 and $8 \%$ in developed countries (De Maeyer, 1985). In 2000, the International Food Policy Research Institute did not find significant changes in the prevalence of anaemia over the previous 13 years. The prevalence of IDA in developing countries was $42 \%$, and $17 \%$ in developed countries (United Nations Administrative Committee on Coordination/Sub-committee on Nutrition, 2000). It was higher in Africa and Asia where it reached 42 and $53 \%$, respectively. In the American region, it was $30 \%$ in
Central American countries, and $26 \%$ in South America (Freire, 2003). The lowest prevalence $(2-5 \%)$ is found in Europe and North America (United Nations Administrative Committee on Coordination/Sub-committee on Nutrition, 2000; Fig. 1). Among Spanish children aged between 6 and 36 months, the prevalence of IDA varies between 4 and $12 \%$ and among children and adolescents between 0 and $3 \%$. This prevalence is superior to that registered in some countries where programmes have been developed to enrich foods with Fe, such as the Nordic countries and Italy, in which the prevalence of anaemia in childhood has been reduced to less than $1 \%$ (Anon., 1997).

\section{Consequences of anaemia and iron deficiency}

IDA has grave consequences especially for children under 5 years of age due to its effects on their physical and mental development and social performance. Children who suffered IDA during the first 2 years of life have lower school performance (Sayed et al. 1999). It is also associated with alterations in cellular immune response, which translates into higher morbidity rates by acute infectious diseases (Freire, 1998). It is also associated with decreased capacity to undertake activities requiring muscular resistance (Beard \& Tobin, 2000).

It is important to note that the degree of anaemia or $\mathrm{Fe}$ deficiency suffered by women during pregnancy is proportional to the child's Fe reserve at birth and to the earlier 


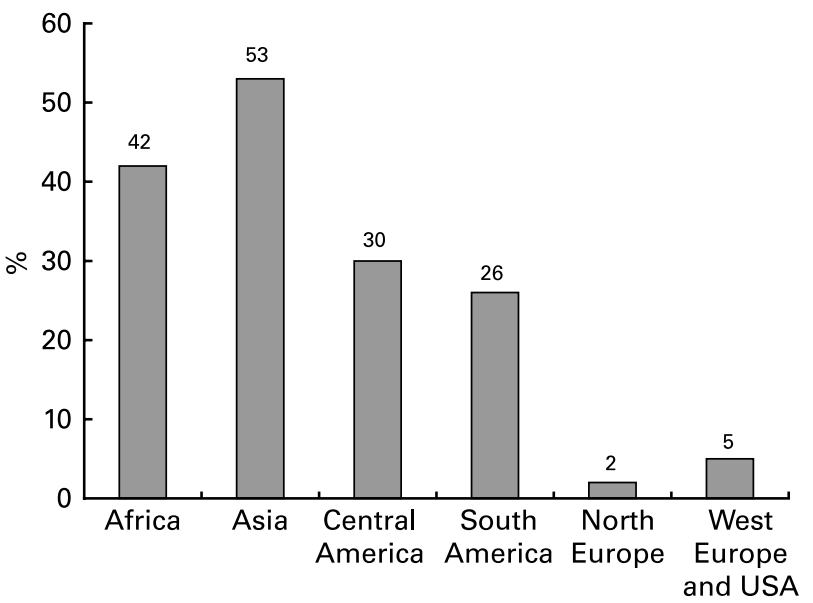

Fig. 1. Prevalence of anaemia in children $<5$ years old (United Nations Administrative Committee on Coordination/Sub-committee on Nutrition, 2000; Dietz, 2003)

appearance and degree of gravity of anaemia, which children often develop after 4 months of age (Menendez et al. 1994; Preziosi et al. 1997).

Micronutrient deficiencies participate directly or indirectly as causal factors of chronic malnutrition. This includes severe consequences for mental and physical growth and general health during childhood and for social performance in adult life, and the higher risk for perinatal morbidity and mortality. All of these negative effects have undeniable economic implications for society (Svedberg, 2000). In Venezuela, the costs implied by capacities lost due to IDA are close to $1 \%$ of the gross national product (Ross \& Horton, 1998).

\section{Zinc deficiency}

$\mathrm{Zn}$ participates as a cofactor in a variety of metabolic pathways: energy metabolism, protein synthesis and gene expression. Its deficiency therefore causes retarded growth and interferes with the correct development of neurological function during infancy (Brown et al. 2002). It also produces alterations in the cellular and humoral immune response. These immune alterations may be associated with the greater risk of diarrhoea and other infections, and increased mortality among Zn-deficient populations. The latter risks are reduced after supplementation with $\mathrm{Zn}$. Zn deficiency is estimated to affect one-third of the world's population (Rivera et al. 2001; Hotz \& Brown, 2004).

\section{Vitamin A, folate and vitamin $B_{12}$ deficiencies}

Deficiencies of vitamin A and of folate have deleterious effects on physical growth, as demonstrated in both animals (West, 1991) and man (Hadi et al. 1999; Sedgh et al. 2000). Folic acid and vitamin $\mathrm{B}_{12}$ deficiencies cause megaloblastic anaemia. Vitamin A deficiency is the most frequent cause of blindness in various regions of the world, most particularly in southeastern Asia and in some African countries. Vitamin A deficiency has been suggested as a causal factor of anaemia, although the mechanisms through which it produces anaemia are not well established (Blomhoff \& Smeland, 1994; Lindembaum \& Allen, 1995)

In addition to the classic manifestations of deficiency of some of these vitamins, it has recently been discovered that even moderate deficiencies of some of them are associated with pathologies. For example, folic acid deficiency has been related to congenital neural tube defects (Daly et al. 1995). Vitamin A deficiency increases the mortality risk associated with diarrhoea and measles (West, 1991), and vitamin $C$ deficiency has been implicated in premature rupture of the membranes during pregnancy, as well as premature birth (Casanueva et al. 1991, 1995). In the majority of these associations, supplementation with the relevant vitamins reduces and controls the magnitude of the problem.

Many of these vitamins play a crucial role in the prevention of chronic diseases during adult life due to their antioxidant abilities (Blumberg, 1995).

The enKid comparative study (1998-2000), which included Spain, France, Ireland, Portugal, Germany, England and the United States, demonstrated that children and adolescents are the populations at greatest risk of suffering nutritional deficiencies, in particular of $\mathrm{Fe}$, vitamins $\mathrm{C}, \mathrm{E}$ and $\mathrm{B}_{6}$, and folic acid. In Spain, these deficiencies are related to income level, parental education, geography, rural-urban dwelling, smoking and obesity (Serra-Majem, 2001).

\section{Fortification of foods is an effective, efficient and sustainable alternative to control and reduce the consequences of micronutrient deficiencies}

Several decades ago, food enrichment or fortification emerged as the most efficient and sustainable option in response to the grave consequences associated with micronutrient deficiencies throughout the population. Fortification of foods massively consumed is recognized as the most efficient, safe and low-cost intervention to resolve nutrition problems (International Bank for Reconstruction and Development, 1994; Darnton-Hill, 1999).

\section{Definitions of the types of nutrimental additions to food}

Fortified and enriched foods are products whose original composition is modified through addition of essential nutrients to satisfy the identified specific nutritional needs of defined populations (Pantanelli, 2000). In the early twentieth century, the enrichment of basic foods promoted by the industrialized nations originated a drastic reduction of illnesses, produced by micronutrient deficiencies, identified as major public health problems. In the beginning, food fortification aimed to guarantee an adequate ingestion of such nutrients throughout the population. For example, rickets was brought under control by the incorporation of vitamin $\mathrm{D}$ in milk, and beriberi and pellagra by the addition of thiamin and niacin to wheat and cereals. Margarine is frequently enriched with vitamins $\mathrm{A}$ and $\mathrm{D}$ to avoid a low intake in cases where margarine is used as the sole source of fat.

Recently, food fortification tends to provide additional value to some foods (Latham, 2002). Today, not only recognized nutritional substances with official dietary recommendations are added, but also other substances considered 
beneficial for health (for example, omega-3 fatty acids, taurine, probiotics, etc.).

Enrichment is defined as adding supplemental amounts of nutrients already present in a food; that is, the concentration of those nutrients already present is increased. For example, the addition of thiamin, niacin or Fe to wheat flour.

Fortification is defined as the addition of nutrients not naturally present in a food or nutritional vehicle. Some examples are the addition of vitamin D to milk or fluoride to salt. Functional foods are also included in this field: they are conventional foods to which substances foreign to them are added. These substances are attributed with the ability to improve health or influence physical performance, although in many instances those benefits have not been unequivocally proven (for example, products combining vitamins $\mathrm{A}, \mathrm{C}$ and $\mathrm{E}$ as antioxidants, energy drinks or probiotic milk products; Pantanelli, 2000).

\section{Examples of successful food fortification}

At the global level, various basic staples such as wheat flour, salt, sugar and other condiments have been enriched with $\mathrm{Fe}$, vitamin $\mathrm{A}$, I, and other micronutrients, as the most cost-effective and sustainable option to eliminate micronutrient deficiencies (Salgueiro et al. 2002). The population of industrialized countries receives an abundant supply of vitamin A through enrichment of foods such as margarines and vegetable or canola oil. Many Central American countries, such as Guatemala or Honduras, have successful programmes enriching sugar with vitamin A (UNICEF/Micronutrient Initiative, 2004).

Salt iodization is one of the most successful enrichment programmes. Implemented in many countries since the 1970s, the salt iodization programme was adopted worldwide in 1990. Iodized salt is now available for 1.5 billion consumers throughout the world, saving millions of small children from mental retardation each year (UNICEF, 1998).

In 1996, Bolivia was the first country to achieve certification for the elimination of illnesses associated with I deficiency as a public health problem. That success was the result of several coordinated actions, i.e. legislation which transformed the political decision into a public policy, and 13 years of coordinated work between salt producers, the government and international cooperation institutions (UNICEF, 1998).

The Mexican National Nutrition Survey of 1999 revealed that $50 \%$ of infants between 12 and 24 months of age and $20 \%$ of Mexican school children suffered anaemia, most due to Fe deficiency (Villalpando et al. 2003).

In response to this problem, a task force including the federal government, industry and academia proposed the fortification of milk with $\mathrm{Fe}, \mathrm{Zn}$, folic acid and vitamin $\mathrm{C}$ under one of the oldest social programmes in Mexico (LICONSA). This milk is distributed to 5 million beneficiaries aged 6 months to 12 years. An effectiveness evaluation of the fortification strategy, carried out among 800 children between 12 and 30 months of age at the beginning of the intervention, found a $25 \%$ reduction in the prevalence of anaemia 6 months after intervention in comparison with a group treated with non-fortified milk (unpublished data).
In Chile, wheat flour fortification began in 1951 with B complex vitamins (thiamin, niacin and riboflavin, $\mathrm{Fe}$, and $\mathrm{Ca}$ ). The original vitamin pre-mix has undergone changes over time. In 1967, the Fe composite was changed to ferrous sulfate. Folic acid was added in 2000 , and the possibility of adding vitamin $\mathrm{B}_{12}$ has recently been considered (Hertrampf, 2003; Hertrampf and Cortes, 2004). As a result of this intervention, Chile has one of the lowest incidences of anaemia among developing countries (8\% in school-aged children), comparable to that of developed countries. Nevertheless, until recently a high prevalence of anaemia still persisted among children under 5 years of age as well as in pregnant women. In an effort to reduce childhood anaemia, in 1999 ferrous sulfate and vitamin $\mathrm{C}$ were added to milk distributed under an existing programme (Purita milk; Olivares et al. 2003). One year after the programme was implemented, a decrease of 20 percentage points was observed in anaemia prevalence among this population group (28.8 v. 8.8\%; Hertrampf, 2003; Torrejón et al. 2004).

During the economic crisis of 1983 in Venezuela, the lowincome population (approximately $80 \%$ of Venezuelans) reduced its consumption of nutritious foods, which was reflected in an increased prevalence of Fe deficiency. In response, in 1993 the Venezuelan Government through the Special Commission on Enriched Foods initiated a fortification programme of wheat and cornflour with ferrous fumarate. Also thiamin, riboflavin and niacin were added.

Both cereals represent $45 \%$ of total energy consumption among the Venezuelan population. In school-aged children and adolescents, the fortification of these flours resulted in a reduction in the prevalence of IDA from 37 and $19 \%$ respectively in 1992, to 15 and $10 \%$ in 1994 (García-Casal and Layrisse, 2002).

\section{Recommendations for successful food fortification programmes}

Many of the fortification programmes proved successful; however, the practicalities of the enrichment process are complex. They demand that government and industry act together. Recent experience indicates that enrichment is successful when the food manufacturers participate from the beginning in the production of norms and in the solution of technical and market problems. Those are the foundations of the programme's success or failure. All actors must contribute in a coordinated way to the success of the programme, ranging from the producers to the consumer, on whose state of nutrition the programme will have an effect (Maberly, 2003).

Additional considerations are the type of fortifier to be added, its bioavailability, and the adequate balance between substances that inhibit or facilitate absorption. Adequate vehicles for food fortification must also be identified. They must be consumed extensively by the population and of reasonable price. For example, staples like wheat, corn or rice, sauces and condiments offer important advantages as fortification vehicles (Thuy et al. 2003) given that they form part of the habitual diet in many countries. For example, fortified soy or fish sauce has proven to be an excellent food fortification vehicle in Vietnam. 
Evaluation of the impact of food fortification on the target population is necessary for feedback and in some cases for re-engineering the formulation or the programme as a whole.

The effectiveness and efficiency of fortified foods relies largely on negotiations between researchers, politicians, producers and consumers. A multisector effort is required linking relevant government organizations, public health organizations, academia, producers, food distributors and even consumers, towards the common goal to improve the population's nutritional state.

Occasionally fortification may have positive and negative commercial consequences. Manufacturers will appreciate the recognition of their efforts, allowing reasonable claims that may help in achieving their marketing aims. In other cases changes in the sensorial characteristics of a product (taste, appearance or smell) may negatively affect sales and market participation; those should be carefully tested and avoided. One case that exemplifies this occurred in Venezuela in the late 1980s, when cornflour was enriched with ferrous fumarate. Instead of its usual white colour, the flour was grey in the market trials. Fearing that consumers would reject the product, flour manufacturers resisted fortification. The situation was solved in 1992 when the Venezuelan National Institute of Nutrition recommended that the flour be enriched with a mixture of Fe compounds that did not alter the colour of the flour (Layrisse et al. 1996).

In 1974, in Guatemala, the enrichment of sugar with vitamin A was approved by law. The fortification programme quickly fell apart because the producers were not convinced of its effectiveness and the necessary foreign currency to buy the vitamin was unavailable. As a result, the law was not enforced. The programme was rescued 10 years later when the Nutrition Institute of Central America and Panama and UNICEF, explaining the relevance of enrichment, provided technical assistance to manufacturers and helped them obtain vitamin $\mathrm{A}$ at below-market prices and through donations.

The Panamanian Health Ministry currently enforces similar laws: when sugar with low levels of vitamin A is found in random testing, the manufacturer first receives a warning and if the manufacturer continues to fail to comply, receives either a fine or closure of their business (UNICEF, 1998).

It is essential to monitor the entire process to guarantee that enriched products reach quality norms. In Chile, Fe enrichment of wheat flour began in the early 1950s. However, quality monitoring and supervision did not begin until 1967, and evaluation of the effectiveness of the programme until 1975, when the first national survey of Fe status among the population was undertaken (Hertrampf, 2003).

In addition, it is strongly recommended that enrichment be mandatory. In addition the manufacturers should be convinced of the benefits of enrichment, in order to assure an equal burden among all individual factories, and to eliminate any possible resistance.

In addition to the nutritional value achieved by food fortification, it offers several advantages: it does not alter the taste and smell of the food; it does not require people to change their eating habits or be convinced of the need to consume a particular product; there is little risk of excess consumption because the added micronutrient has been calculated in accordance with its requirements and dietary recommendations; the final cost of fortification is usually very low and when transferred to the consumer it does not impact on the price; and finally, it is more efficacious than any other nutritional intervention.

\section{General observations}

Fortification of foods is a convenient population strategy to reduce and control micronutrient deficiencies especially in regions of the world where available foods cannot fulfil the intake requirements of the population. Fortification should, therefore, be considered as one policy to combat micronutrient deficiencies.

\section{References}

Anon. (1997) La carencia de hierro, un problema frecuente en España. Jano Diario, 6 October.

Beard JL \& Tobin BW (2000) Iron status and exercise. Am J Clin Nutr 72, Suppl., 594S-597S.

Blomhoff HK \& Smeland EB (1994) Role of retinoids in normal hematopoiesis and the immune system. In Vitamin A in Health and Disease, pp. 451-484 [R Blomhoff, editor]. New York: Marcel Dekker.

Blumberg JB (1995) Considerations of the scientific substantiation for antioxidant vitamins and $\beta$-carotene in disease prevention. Am J Clin Nutr 62, 1521s-1526s.

Brown K, Peerson JM, Rivera J \& Allen L (2002) Effect of supplemental zinc on the growth and serum zinc concentration of prepubertal children: a meta-analysis of randomized controlled trials. Am J Clin Nutr 75, 1062-1071.

Casanueva E, Avila H, Polo E, Tejero E, Narcia ML \& Pfeffer F (1995) Vitamin C status, cervico-vaginal infection and premature rupture of amniotic membranes. Arch Med Res 26, S149-S152.

Casanueva E, Magaña L, Pfeffer E \& Baez A (1991) Incidence of premature rupture of membranes in pregnant women with low leukocyte levels of vitamin C. Eur J Clin Nutr 45, 401-405.

Daly LE, Kirke PN, Mohillo A, Weir DG \& Scott JM (1995) Folate levels and neural tube defects. Implications for prevention. JAMA 274, 1698-1702.

Darnton-Hill I, Mora JO, Weinstein H, et al. (1999) Iron and folate fortification in the Americas to prevent and control micronutrient malnutrition: an analysis. Nutr Rev 57, 25-31.

De Maeyer E \& Adiels-Tegman M (1985) The prevalence of anemia in the world. World Health Stat $Q$ 38, 302-316.

Dietz W (2003) Global problem of deficiencies in iron, folic acid, and vitamin $\mathrm{B}_{12}$, and food fortification as a key public health intervention. Paper presented at Fortificación de harinas con hierro, ácido fólico y vitamina $B_{12}$ en las Américas, Organización Panamericana de la Salud (OPS/OMS), Centros para el Control y Prevención de Enfermedades (CDC), March of Dimes (MOD), Fondo de las Naciones Unidas para la Infancia (UNICEF), Santiago, Chile, 9-10 October.

Freire WB (1998) La anemia por deficiencia de hierro, estrategias de OPS/OMS para combatirla. Salud Publica Mex 40, 199-205.

Freire W (2003) Situación de hierro, folatos y vitamina $B_{12}$ en las Américas. Paper presented at Fortificación de harinas con hierro, ácido fólico y vitamina $B_{12}$ en las Américas, Organización Panamericana de la Salud (OPS/OMS), Centros para el Control y Prevención de Enfermedades (CDC), March of Dimes (MOD), Fondo de las Naciones Unidas para la Infancia (UNICEF), Santiago, Chile, 9-10 October.

García-Casal MN \& Layrisse M (2002) Iron fortification of flours in Venezuela. Nutr Rev 60, S26-S29.

Hadi H, Stoltfus RJ, Moulton LH, Dibley MJ \& West KP (1999) Respiratory infections reduce the growth response to vitamin A sup- 
plementation in a randomized controlled trial. Int $J$ Epidemiol $\mathbf{2 8}$, 874-881.

Hertrampf E (2003) Fortificación de la harina de trigo en Chile: hierro y ácido fólico. Paper presented at Fortificación de harinas con hierro, ácido fólico y vitamina $B_{12}$ en las Américas, Organización Panamericana de la Salud (OPS/OMS), Centros para el Control y Prevención de Enfermedades (CDC), March of Dimes (MOD), Fondo de las Naciones Unidas para la Infancia (UNICEF), Santiago, Chile, 9-10 October.

Hertrampf E \& Cortes F (2004) Folic acid fortification of wheat flour: Chile. Nutr Rev 62(6 Pt 2), S44-S48.

Hotz C \& Brown KH (eds) (2004) Assessment of the risk of zinc deficiency in populations and options for its control. IZINCG Technical Document \#1. Food Nutr Bull 24, 186.

International Bank for Reconstruction and Development (1994) Enriching Lives: Overcoming Vitamin and Mineral Malnutrition in Developing Countries. Washington, DC: World Bank.

Latham MC (2002) Nutrición Humana en el Mundo en Desarrollo. Colección FAO: Alimentación y Nutrición no. 29. Rome: Organización de las Naciones Unidas para la Agricultura y la Alimentación.

Layrisse M, Chávez JF, Méndez-Castellano H, Bosch V, Tropper E, Bastardo B \& González E (1996) Early response to the effect of iron fortification in the Venezuela population. Am J Clin Nutr 64, 903-907.

Lindembaum J \& Allen RH (1995) Clinical spectrum and diagnosis of folate deficiency. In Folate in Health and Disease, pp. 43-74 [LB Bailey, editor]. New York: Marcel Dekker.

Maberly GF (2003) Fortification of wheat flour is a public-privatecivic investment in each nation. In Strategic Plan 2003-2004, Flour Fortification Initiative, pp. 6-13. Atlanta, GA: Emory University.

Menendez C, Todd J, Alonso PL, et al. (1994) The effects of iron supplementation during pregnancy, given by traditional birth attendants, on the prevalence of anemia and malaria. Trans $R$ Soc Trop Med Hyg 88, 590-593.

Olivares M, Hertrampf E, Pizarro F \& Walter T (2003) El enriquecimiento con hierro de la leche: la experiencia chilena (Iron fortification of milk in Chile). Food Nutr Agric 32, 69-73.

Pantanelli A (2000) Alimentos fortificados y enriquecidos. Revista Alimentos Argentinos 14, 1-15.

Preziosi P, Prual A, Galan P, Daouda H, Boureima H \& Hercberg S (1997) Effects of iron supplementation on iron status of pregnant women: consequences for newborns. Am J Clin Nutr 66, 1178-1182.

Rivera J, Brown K, Hotz C \& Ruel M (2001) Zinc deficiency: issues for public health, assessment, and prevention. In Modern Aspects of
Nutrition: Present Knowledge and Future Perspectives [I Elmadfa, E Anklam and JS König, editors]. Proceedings of the 17th International Congress of Nutrition. 27-31 August, Vienna, Austria. Basel: Karger.

Ross JS \& Horton S (1999) The Economic Consequences of Iron Deficiency. Ottawa: Micronutrient Initiative.

Salgueiro MJ, Zubillaga M, Lysionek A, Caro R, Weill R \& Boccio J (2002) Fortification strategies to combat zinc and iron deficiency. Nutr Rev 2, 60, 52-58.

Sayed NE, Gad A, Nofal L \& Netti G (1999) Assessment of the prevalence and potential determinants of nutritional anemia in Upper Egypt. Food Nutr Bull 20, 417-421.

Sedgh G, Herrera MG, Nestel P, elAmin A \& Fawzi WW (2000) Dietary vitamin A intake and nondietary factors are associated with reversal stunting in children. J Nutr 130, 2520-2526.

Serra-Majem Ll (2001) Factors affecting nutrient intake in children. Ann Nutr Metab 45, Suppl. 1, 602.

Svedberg P (2000) Poverty and Undernutrition. New York: Oxford University Press.

Thuy PV, Berger J, Davidsson L, Khan NC, Lam NT, Cook JD, Hurrell RF \& Khoi HH (2003) Regular consumption of NaFeEDTA-fortified fish sauce improves iron status and reduces the prevalence of anemia in anemic Vietnamese women. Am J Clin Nutr 78(2), 284-290.

Torrejón C, Castillo Duran C, Hertrampf E \& Ruz M (2004) Zinc and iron nutrition in Chilean children fed fortified milk provided by the complementary national food program. Nutrition 20, $177-180$.

UNICEF (1998) Estado Mundial de la Infancia, p. 64 Ginebra: UNICEF. UNICEF/Micronutrient Initiative (2004) Vitamin \& Mineral Deficiency Reports. New York: UNICEF. 2004.

United Nations Administrative Committee on Coordination/SubCommittee on Nutrition (2000) Nutrition Throughout the Life Cycle. 4th Report on The World Nutrition Situation. Geneva: $\mathrm{ACC} / \mathrm{SCN}$ in collaboration with International Food Policy Research Institute.

Villalpando S, Shamah Levy T, Ramírez-Silva CI, Mejía-Rodríguez F \& Rivera J (2003) Prevalence of anemia in children $1-12$ years of age. Results from a national probabilistic survey in Mexico. Salud Publica Mex 45, Suppl. 4, S490-S498.

West KP (1991) Dietary vitamin-A deficiency: effects on growth infection, and mortality. Food Nutr Bull 19, 119-131.

World Health Organization/UNICEF/United Nations University (2001) Iron Deficiency Anaemia: Assessment, Prevention, and Control. Geneva: WHO/UNICEF/UNU. 